\title{
The Reform of the Civil Service System in China 1993-2009
}

\author{
Guzel 'Vasilevna Rakhimova', Dmitry Evgenyevich Martynov ${ }^{1}$, Yulia Aleksandrovna Martynova ${ }^{1}$ \& Glushkova \\ Svetlana Yurievna ${ }^{1}$ \\ ${ }^{1}$ Kazan Federal University, Russia \\ Correspondence: Dmitry Evgenyevich Martynov, Kazan Federal University, Russia. E-mail:
}

dmitrymartynov80@mail.ru

Received: June 9, 2019

Accepted: August 25, $2019 \quad$ Online Published: August 31, 2019

doi:10.5539/jpl.v12n5p15

URL: https://doi.org/10.5539/jpl.v12n5p15

\begin{abstract}
The paper is devoted to the analysis of public service reforms in China in the period of 1993 - 2009. The reforms, in part, took advantage of the positive experience of the Chinese past. They were aimed at improving the efficiency of civil servants by introducing more competitive selection processes, incentives to encourage activities and tightening control and supervision. The processes of selection, appointment, training, dismissal and retirement of civil servants were also streamlined. The chronological scope of the study is determined by the dates when the Interim Regulation on Civil Servants (1993) was adopted, and up to the date of adoption and implementation of the full-fledged Law on Civil Servants (2006). Then the first consequences of the reforms began to be felt: the legalization and normalization of the personnel system, the motivation to show high moral standards for civil servants who could gain respect from the people, and the activation of their high moral and business qualities. In part, the adoption of these laws was accompanied by the coming to power of the fourth generation of leadership of the CPC and PRC.

Keywords: China, civil service, reforms in China, modernization in China, People's Republic of China, Chinese communist party

\section{Introduction}

Since 1993, the Chinese government has taken significant steps to transform the country's public service system. It is the presence of an effectively organized public service that indicates the level of development of the country and ensures its prestige. Today, the central departments of China are staffed by highly qualified and dedicated employees and in many respects comply with the principles formulated by the government and going back to the traditional Confucian system of values. However, it is worth noting that the quality of public service varies greatly depending on the different provinces and regions, as more developed areas have more opportunities to maintain a high level of work of civil servants.
\end{abstract}

\section{Methods}

In the process of writing the work, a number of methods were used: the historical method, which allowed to identify the main stages of the formation and development of public service, a systematic method for analysing the content and interconnection of all components of the reforms, and structural-functional to analyse the changes that occurred during the reform of public service in China.

\section{Results}

On August 14, 1993, State Council Prime Minister Li Peng signed the "Provisional Regulation on Public Servants," which has entered into force in October of the same year. After that, the State Council issued a set of specific rules for its implementation, and each provincial body prepared its own detailed instructions for ensuring compliance with Regulation. The Regulation applied only to those who were employed in the public sector, setting also an example of personnel management in other sectors. Since the Chinese Communist Party decided to conduct the management of its cadres in accordance with this Regulation, the leadership of the party cadres followed its example. The Chinese Communist Youth League and the China Women's Association have also decided to take a similar path. In general, it was assumed that the civil service system would be implemented throughout the country within three years, or, possibly, a little longer.

The situation reflected the regime's readiness to reform the personnel management system in order to promote the creation of a cohesive and effective government bureaucracy that would lead China to the 21st century. Song Ping, the former head of the Organisational Department in the Central Committee of the Chinese Communist Party, briefly described the intention of the communist regime to develop a public service system without undermining 
the party's dominant power: "We must adhere to the principle that the party leads the staff, while gradually creating and improving the management system based on scientific classification, competition and incentive mechanisms that will enable talented people to manifest and use their ability ".

In general, the Provisional Regulation guaranteed the safety of the workplace by ensuring stable working conditions, reasonable pay and protection from arbitrary dismissals. In addition to the fundamental rights and duties, the Regulation also emphasized the right of civil servants to "criticize and make suggestions to the leaders", but "implementation of the party and state political line" is mandatory. One of the interesting points of the Regulation is the question on a procedure for removal records of past punishments of officials that is substantially equal to their rehabilitation. If guilty civil servants repent of their mistakes, the record of punishment may be deleted after a certain period of time.

Based on all of the above, we can conclude that the Provisional Regulation on civil servants represents an important step towards creating a modern, competent and rational bureaucracy which is necessary for building socialism with Chinese specifics. However, it should be noted that the civil service system during this period is not yet final and requires significant improvements.

After Hu Jintao became the new party leader, the CPC stepped up its anti-corruption campaign. Based on the requirements put forward in "the CPC's decision to strengthen the governing potential of the party", the CPC issued in early 2005 the Program for the creation of a system of punishment and prevention of corruption. In the Program, there was an attempt to create a system for the preventive fight against rampant corruption in China and identify eight areas for its eradication already in the bud: 1) implement the law on administrative licensing, reform the system of administrative expertise and approval for positions; 2) deepen the reform of the financial management system and realize the goal of separate planning of expenses and incomes; 3 ) implement the decision of the State Council on the reform of the investment system and strengthen supervision of state policy regarding investments; 4) to intensify the staff system reform and to create a supervision mechanism for the selection and appointment of personnel; 5) carry out the reform of the supervision system in accordance with the "Regulation on the Party Control in the CPC (trial)"; 6) continue the financial reform of enterprises and improve banking supervision; 7) to intensify judicial reform and strengthen judicial supervision; and 8) manage and control various public organizations, including professional organizations and intermediary agencies.

However, despite the various efforts undertaken, corruption in Chinese society remains a serious problem. The Chinese government also faced new challenges. For example, many corrupt officials fled abroad before their criminal activities were uncovered. For example, it was reported that only in the province of Fujian 69 corrupt officials left the country during the first half of 2004.

The PRC Law on Civil Servants was enacted on January 1, 2006, replacing the Provisional Regulation. The Law contains significant differences from the previous regulatory document. So, chapter I, "General Provisions", is supplemented by Deng Xiaoping's new party guidelines: on "three representations" (this means that the party represents the interests of the whole people, all productive forces and culture) and on the course towards building a socialist rule of law, which must be guided. The law emphasizes that the system for appointing and approving public servants is subordinate to the principle of the party leadership and that the prerogative of the staff deployment remains with the Chinese Communist Party. Compared to the Provisional Regulations, the law is supplemented by chapter XVII ("Legal liability"). It lists all violations of the law for the commission of which a public servant can be punished by condemnation to the criminal prosecution, as well as a list of positions that fall under this article. These violations include, for example, the adoption of decisions concerning staff issues in the absence of a quota of staff or a sufficient number of posts, recruitment of an employee who does not have the necessary competence, as well as disclosure of examination topics when enrolling in posts, violation of discipline in exams, etc.

The law defined a civil servant that was not in the Provisional Regulation. The requirements for candidates for civil servants were clarified, namely: citizenship of the People's Republic of China, age 18 years and older, support for the Constitution of the People's Republic of China, good behaviour, good health, adequate for normal performance of official duties, high cultural level, working capacity and competence corresponding to official duties. It is stipulated that the enrolment of civil servants for positions in the central state apparatus and institutions under this apparatus is carried out by the Ministry of Personnel. Enrolment in local authorities is carried out by personnel departments of provincial level; they have the right to involve the competent authorities of cities and regions in this work. Persons subjected to criminal punishment, dismissal from the civil service, as well as on other grounds established by law cannot be accepted for service in the central and local state apparatus.

Applicants for the position pass oral and written exams, the results of which are enrolments. Newly recruited civil servants must withstand a one-year probationary period. If necessary, civil servants can work part-time outside their institution, but they do not receive remuneration for such work. 
In contrast to the Provisional Regulation, the new Law introduced an invitation category. Invitations are initiated by agencies and authorized by the competent staff affairs authorities (provincial level and higher). It is acceptable to invite employees to the most important special and auxiliary positions. Those invited must sign a written agreement with the appropriate institution for a period of one to five years. It is forbidden to invite employees to posts related to state secrets.

The declaration of income of leading core workers of party and state bodies of the county level and higher are regulated by the relevant resolution approved by the Central Committee of the CPC and the State Council and sent out by the chancelleries of these bodies on April 30, 1995. It does not apply to all public servants, but it also applies to leading core workers of public organizations at the county level (including the People's Political Advisory Council), as well as to managers of large and medium enterprises. In addition to wages, they must declare all types of bonuses and grants, fees and income from economic activity under a contract of rent and lease.

A civil servant may resign by dismissal or resignation. Dismissal is made on the basis of an application from the employee. It must be reviewed within 30 days (within 90 days for executives). The law provides for cases when dismissal is impossible, for example, if an employee holds a post related to state secrets, and the deadline for removing secrecy has not yet expired, or when an important state task for which the employee is responsible has not yet been completed. Dismissal is not possible during the audit or discipline inspection in the institution where the dismissed person serves, as well as in some other cases.

The resignation is not conditioned by the desire of the employee. He may be dismissed if for two consecutive years during the certification he was found to be inappropriate for the position or for violation of discipline, for example, for absenteeism after a vacation for more than 15 days, for absenteeism 15 days in a row or more than 30 days for years and in some other cases. At the same time, the Law provides for cases when an employee cannot be dismissed, in particular, it cannot be done with pregnant women and nursing mothers, with civil servants who have been injured in the service, etc.

Civil servants retire upon reaching the retirement age established by the state or with complete disability. If desired, civil servants with thirty years of experience can retire, even if they're five and less years short of retirement age. Undoubtedly, the implementation of the Law on Civil Servants is an important step towards the creation of a modern civil service system.

\section{Discussion}

Chinese, Western and Russian scientists have different approaches to the problem of Chinese civil service. Chen Zhengming points out that in the 1990s, in order to adapt to a market economy and in connection with the need for deep political and administrative reform, China introduced a national civil service system. Differences in national and environmental circumstances result in differences in the goals, strategies and specific measures of these changes. The most important task of modernization, both in Russia and in China, is the desire of the authorities to simultaneously achieve greater legitimacy in the eyes of their own population, with the integration of the country into the circle of developed states. However, due to the lack of a single legal field and social disunity, real modernization is replaced by symbolic steps, which lead to a radicalization of the mood of the young generation. Studies on the problems of administrative reform in China were carried out by Chinese scholars Guan Haiting, Liu Yi, Zhang Liring, and others.

In Russia, a large amount of literature is devoted to this topic. The extensive list of issues of Chinese political modernization is affected by the research of the following Russian scientists: P.M. Aslanova, Ya.M. Berger, V.G. Burova, Yu.M. Galenovich, L.P. Delyusina, K.A. Egorova, L.M. Gudoshnikova, T.M. Emelyanova, V.V. Karlusova, M.V. Karpova, K.K. Kokareva, O.V. Litvinova, H.L. Mamaeva, M.L. Titarenko, E.P. Pivovarova G.A. Stepanova, and others.

Modern researches-sinologists emphasize in Chinese modernization processes the special role of the traditional culture of the PRC, the heritage of Confucius, Shang Yang and Mencius. Thus, the relationship between modernity and traditions in the political culture of the PRC as a whole was studied by L.S. Perelomov and A.A. Abramova, and the role of Confucianism and Legism in the political practice of China by M.B. Zhamsaev.

\section{Summary}

Civil Service Reforms 1993-2012 were aimed at improving the efficiency of civil servants by introducing more competitive selection processes, and incentives to encourage activities and tightening control and supervision. The processes of selection, appointment, training, dismissal and retirement of civil servants were also streamlined.

Thus, having determined the main stages and analysing the content of public service reforms in the PRC from 1993 to 2012, the following conclusions can be drawn:

The reform began in 1993 when the Interim Regulation on civil servants was adopted. Its content included many aspects of administrative work, such as job classification, rights and obligations, the procedure for appointing and 
evaluating employee performance, a system of reward and punishment, training and exchange, promotion and demotion, appointment and dismissal, resignation and layoffs of civil servants.

The transition to the next stage was 2006. Then the Law on Civil Servants was published and put into practice; it marked the legalization and normalization of the personnel system for civil servants, contributed to the formation of the right vector for the development of the personnel corps, motivation for the manifestation of high morality of civil servants, able to gain respect from the people, intensification of high moral and business qualities.

Thirdly, it should also be noted that China's public service reforms are directly related to the country's political events. For example, the year 2002 is considered a milestone both in the development of the public service system in China and in general in the development of China. It was in this year that the Secretary General of the CPC Central Committee left his post, freeing up the path to power for the "fourth generation" of leaders represented by Hu Jintao, which has marked a new era in China.

\section{Conclusions}

Scientists still disagree on the effectiveness of the public sector reform process in China, which began in 1993 and was extended by 2006 legislation. Kjeld Erik Brødsgaard and Gan Chen argue that the Chinese government policy of creating a more clearly defined human resource of civil servants and public sector employees will ultimately lead to a less egalitarian public sector. The "Iron rice bowl" status will persist as the Communist Party tries to keep its employees loyal to maintain its power, while it will be more difficult for most budget institutions to attract the best staff. Thus, unequal opportunities can be a serious obstacle to efforts to strengthen the overall potential of the public sector.

The reforms of 1993 and 2006 led to the creation of a more efficient and effective public service, but some problems still remain unresolved. For example, corruption is widespread in many areas of the public sector. The actions taken by the government to identify and punish violators did not bring the country to the desired results. The widely proclaimed wage reform aimed at promoting a cleaner government also fell short of expectations

\section{Acknowledgements}

The work is performed according to the Russian Government Program of Competitive Growth of Kazan Federal University.

\section{References}

Berman, E. M. (2017). Public Administration in East Asia: Mainland China, Japan, South Korea, Taiwan. London: Routledge. https://doi.org/10.4324/9781315089317

Brødsgaard, K. E. (2014). Globalization and Public Sector Reform in China. London: Routledge. https://doi.org/10.4324/9781315857626

Cheng, J. Y. S. (Ed.). (1998). China in the Post-Deng Era. Hong-Kong: Chinese University Press.

Devyatkov, A. V., \& Makarychev, A. S. (2012). Modernization as a problem of Russian-European relations. Politicheskaya nauka, (2), 73-87.

Gudoshnikov, L. (2008). Metamorphosis of civil service in China. Otechestvennyye zapiski, 42(3), 247-253.

Gudoshnikov, L. M. (2006). Reforming the Civil administration system in the PRC. Problemy Dal'nego Vostoka, (4), 34-46.

Hao, L. (2015). Functioning and development of the civil service system in the People's Republic of China at the present stage: dissertation for the degree Candidate of Political Sciences. Moscow State University.

Hooghe, I., \& Vermeer, E. B. (Eds.). (2012). China's Legal Reforms and Their Political Limits. London: Routledge.

Liu, Y. (2006). Administrative reform in Russia and China: the experience of comparative analysis: the internal policy of the states",Vestnik Moskovskogo universiteta. Ser. 12: Politicheskiye nauki, (2), 69-75. https://doi.org/10.4324/9780203037300

Margalit, Y. (2013). Explaining Social Policy Preferences: Evidence from the Great Recession. American Political Science Review, 107(1), 80-103. https://doi.org/10.1017/S0003055412000603

Martynov, D. E. (2006). The traditional basis and modern policy of the CCP (to the understanding of "Chinese specifics"). Vestnik TISBI. Nauchno-informatsionnyy zhurnal, (1), 39-45.

Stepaniants, M., \& Kohanovskaya, R. (tr.), Behunuak, J. (Ed.). (2002). Introduction to Eastern Thought. Rowman \& Littlefield Publ.

Vinogradov, A. V. (2008). The Chinese model of modernization. The search for a new identity (2nd ed.). Moscow: NOFMO Publ. 
Wang, X. Q. (2012). China's Civil Service Reform. London: Routledge.

Wong, J., \& Lai, H. Y. (Eds.). (2006). China Into the Hu-Wen Era: Policy Initiatives and Challenges. New Jersey: World Scientific. https://doi.org/10.1142/6070

Yan, F. X., Martynov, D. E., \& Alikberova, A. R. (2018). Introducing the Concept of Modernization in China in the 20th Century. The Journal of Social Sciences Research, (5), 157-160. https://doi.org/10.32861/jssr.spi5.157.160

\section{Copyrights}

Copyright for this article is retained by the author(s), with first publication rights granted to the journal.

This is an open-access article distributed under the terms and conditions of the Creative Commons Attribution license (http://creativecommons.org/licenses/by/4.0/). 